\title{
Komitmen Sumber Daya Manusia Sektor Publik Berbasis Kepemimpinan Spiritual Melalui Spiritualitas Di Tempat Kerja
}

\author{
I G.G Oka Pradnyana ${ }^{(1)}$ \\ I Made Purba Astakoni( ${ }^{(2)}$ \\ Ni Made Satya Utami ${ }^{(3)}$ \\ (1)(2)Prodi Manajemen Sekolah Tinggi Ilmu Manajemen Handayani Denpasar \\ ${ }^{(3)}$ Prodi Manajemen Fakultas Ekonomi \& Bisnis Universitas Mahasaraswati Denpasar \\ Email: okapradnyana63@gmail.com

\begin{tabular}{|l|l|l|}
\hline Diterima: 15 Juli 2020 & Direvisi: 27 Juli 2020 & Disetujui: 30 Juli 2020 \\
\hline
\end{tabular}

\begin{abstract}
This study has several objectives namely; analyze the influence of spiritual leadership on organizational commitment; analyze the influence of spiritual leadership on spirituality in the workplace; analyze the influence of spirituality at work on organizational commitment; analyze the role of spirituality in the workplace as a mediator on the influence of spiritual leadership on organizational commitment. The population in this study were all employees of drinking water companies in the Badung Regency, Tabanan Regency, and PAM Denpasar City, which totaled 902 employees. Sampling was done purposively with a total of 200 respondents. Data collection techniques used were interviews with questionnaires with multiple choice closed. In this study data analysis using the Partial Least Square (PLS) approach. The results showed that the overall evaluation of the model seen from the coefficient of determination can be said to be quite good, Q-Square Predictive Relevance meets existing requirements and Goodness of Fit in a large position then the overall model is quite good. The first hypothesis, which states that spiritual leadership has a significant positive effect on organizational commitment, is not yet acceptable. The second hypothesis, which states that spiritual leadership has a significant positive effect on spirituality at work, is acceptable. The third hypothesis, which states that spirituality at work has a significant positive effect on organizational commitment, is acceptable. Based on testing through the Sobel test, it can be explained that spirituality in the workplace can act as a mediator concerning spiritual leadership to organizational commitment.
\end{abstract}

Keywords: Organizational commitment, Spirituality at workplace and Spiritual Leadership

\section{Pendahuluan}

Tempat kerja bagi masyarakat modern bukan hanya tempat di mana orang-orang bekerja, tetapi tempat dimana mereka menjalin persahabatan, bersosialisasi, dan berusaha menemukan kepuasan batin. Dalam hal ini bisa juga dimaknai merupakan tempat di mana orang berusaha memahami dan memperoleh makna dari kegiatan yang sering disebut "bekerja" dan bagaimana kegiatan ini cocok dengan jalinan kehidupan individu yang lebih luas (Mansor et al., 2013). Spiritualitas adalah sebuah proses dalam kehidupan individu, berupa makna dan tujuan, dan semuanya berdampak pada individu lain dan lingkungannya,termasuk organisasi (Hakim dan Azlimin, 2015). Pencarian makna ini telah mendorong adanya pengakuan bahwa kepemimpinan spiritual dan spiritualitas di tempat kerja adalah suatu realitas yang mempengaruhi kualitas hidup 
serta mengarah pada komitmen dalam organisasi modern. Menurut Fry et al., (2011) Kepemimpinan spiritual memanfaatkan kebutuhan mendasar dari pemimpin dan pengikut untuk kelangsungan hidup spiritual sehingga mereka menjadi lebih berkomitmen dan produktif secara organisasi. Seorang pemimpin spiritual memahami pentingnya karyawan menemukan makna dalam pekerjaan mereka dan menunjukkan kepedulian yang tulus terhadap orang secara utuh, dan juga mengupayakan tempat kerja yang benar-benar sebuah komunitas, yang terdiri dari orang-orang dengan tradisi, nilai dan kepercayaan yang sama.

Kehidupan organisasi mengalami berbagai macam tantangan yang berasal dari dalam maupun luar organisasi. Organisasi yang mampu menghadapi tantangan tersebut akan berkembang dan bertahan (Yogatama \& Widyarini, 2015). Dalam organisasi modern sering dijumpai karyawan mengalami berbagai tekanan,kecemasan,keterasingan antar individu dan kelelahan di tempat kerja (Yogatama \& Widyarini, 2015). Fry et al. (2017) mengungkapkan bahwa perusahaan ataupun organisasi tidak dapat berkembang dalam norma kerja yang penuh tekanan dan pada sisi lain menuntut karyawannya bekerja secara terus menerus demi keuntungan perusahaan.

Salah satu penentu kinerja organisasi adalah spiritualitas (Utami \& Astakoni 2020). Spiritualitas di tempat kerja dibutuhkan karena dapat berdampak pada individu, lingkungan, maupun organisasi (Ke et al., 2017). Memahami spiritualitas di tempat kerja adalah menyadari bahwa manusia merupakan makhluk yang memiliki jiwa dan dapat dipengaruhi oleh pekerjaannya (Ashmos \& Duchon, 2000). Nilai-nilai spiritual di tempat kerja semakin didiskusikan dan diaplikasikan dalam literatur etika bisnis yang dapat dilihat dari sudut pandang individu, kelompok, organisasi, atau interaktif antar yang satu dengan yang lainnya (Milliman et al., 2003). Hal ini terjadi karena organisasi secara perlahan berkembang dari kegiatan ekonomi dan sosial murni ke arena pembangunan spiritual (Fry et al., 2017). Topik mengenai spiritualitas dalam bisnis semakin penting, menarik, dan sudah banyak mewarnai berbagai konferensi, artikel, buku, media-media publikasi, seperti Business Week, Fortune, USA Today, Wall Street Journal, situs online, dan lain sebagainya (Ke et al., 2017). Jangkauan hubungan antara nilai dan etika bisnis baru-baru ini lebih diperluas guna memasukkan nilai-nilai spiritual (Kolodinsky, et.al., 2008). Nilai-nilai spiritual tercakup dalam hubungan antara nilai dan etika bisnis, sebab, konsep spiritualitas memang telah digambarkan dalam teori perilaku organisasional (Luthans, 2009). Kondisi ini menjadi menarik jika dihubungkan dengan pernyataan bahwa tidak hanya fungsi perusahaan yang selama ini jauh dari nilai spiritual, tetapi juga tempat kerja yang selama ini menghalangi berkembangnya dimensi spiritual. Akibat yang terjadi adalah kejenuhan, 
stres, produktivitas rendah, demotivasi, bahkan puncaknya dapat menyebabkan seseorang mengalami depersonalisasi (Sunarso, et.al., 2019). Pada dasarnya pencarian makna dan tujuan merupakan hal utama dan hidup dalam harmoni dengan orang lain dipandang sebagai sesuatu yang sangat penting (Ashmos dan Duchon, 2000).

Studi yang dilakukan oleh Pawar (2009) mengungkapkan sebuah hasil menarik yang menyatakan bahwa spiritualitas organisasi ternyata dapat memberikan pengaruh positif pada pembentukan sikap kerja yang meliputi kepuasan, keterlibatan dan komitmen. Temuan (Ke et al., 2017) mengungungkap hasil studi yang sama yaitu terdapat pengaruh signifikan antara spiritual di tempat kerja dengan komitmen. Analisis hubungan spiritualitas di tempat kerja dengan berbagai sikap kerja telah banyak diuji, namun peran spritualitas di tempat kerja sebagai variabel mediasi dalam kaitan kepemimpinan spiritual dengan komitmen sumber daya manusia masih belum banyak dilakukan. Spiritual di tempat kerja mengacu pada pembentukan pembelajaran organisasi melalui penggunaan motivasi intrinsik karyawan untuk mencapai transformasi organisasi (Ashmos dan Duchon, 2000).

Studi ini dilakukan pada perusahaan daerah air minum di Provinsi Bali yaitu perusahaan daerah air minum (PDAM) Kabupaten Badung, perusahaan daerah air minum (PDAM) Kabupaten Tabanan dan perusahaan air minum (PAM) Kota Denpasar. Dipilihnya ketiga daerah ini mengingat adanya kerja sama diantaranya dalam mentuk pemakaian jaringan pipa bersama, sumber air yang saling terkait dalam bentuk perusahaan air minum "Sarbata" dan secara historis PDAM Kabupaten Badung dan PAM Kota Denpasar merupakan satu perusahaan daerah di tahun 1990an. Penelitian ini memiliki tujuan menganalisis pengaruh kepemimpinan spiritual terhadap komitmen organisasi, menganalisis pengaruh kepemimpinan spiritual terhadap spiritualitas di tempat kerja, menganalisis pengaruh spiritualitas di tempat kerja terhadap komitmen organisasi, menganalisis peran spiritualitas di tempat kerja sebagai pemediasi pada pengaruh kepemimpinan spiritual terhadap komitmen organisasi.

\section{Telaah Literatur dan Kajian Pustaka}

\section{Komitmen Sumberdaya Manusia}

Meyer dan Allen (1991) mengungkapkan bahwa komitmen organisasi memiliki tiga dimensi yaitu komitmen afektif, komitmen normatif dan komitmen berkelanjutan. Ketiga dimensi ini dikembangkan dari teori awal yang dikemukakan oleh Mowday, et.al., (1982) yang mengungkapkan bahwa komitmen organisasi terdiri dari dua jenis, yaitu komitmen sikap 
(attitudinal commitment) dan komitmen perilaku (behavioral commitment). Dua jenis awal komitmen organisasi tersebut kemudian berkembang, komitmen sikap dikembangkan menjadi komitmen afektif dan komitmen normatif, sedangkan komitmen perilaku dikembangkan menjadi komitmen berkelanjutan (Allen dan Meyer, 1990). Komitmen organisasi menunjuk pada pengidentipikasian tujuan karyawan dengan tujuan organisasi, kemauan mengerahkan segala daya untuk kepentingan organisasi dan keterikatan untuk tetap menjadi bagian dari organisasi serta mempertahankan nilai-nilai organisasi (Utami, 2016). Mowday, et.al., (1982) dalam Luthans, (2009) mengemukakan bahwa sebagai sikap, komitmen organisasi (organizational commitment) paling sering didefinisikan sebagai;1) keinginan kuat untuk tetap sebagai anggota organisasi tertentu;(2)keinginan untuk berusaha keras sesuai keinginan organisasi;(3) keyakinan tertentu, dan penerimaan nilai dan tujuan organisasi. Armstrong (2006) mengemukakan bahwa komitmen organisasional merujuk pada kecintaan dan loyalitas. Sopiah (2008) menyimpulkan bahwa komitmen organisasional adalah suatu ikatan psikologis karyawan yang ditandai dengan adanya kepercayaan dan penerimaan yang kuat atas tujuan dan nilai-nilai organisasi, kemauan untuk mengusahakan tercapainya kepentingan organisasi, dan adanya keinginan yang kuat untuk mempertahankan kedudukan sebagai anggota organisasi. Berdasarkan paparan tersebut dapat dikatakan bahwa komitmen kerja atau komitmen organisasional adalah suatu keadaan dimana individu menganut nilai-nilai dan tujuan organisasi serta merasa ikut memiliki organisasi sehingga memutuskan untuk tetap tinggal dalam organisasi.

\section{Kepemimpinan spiritual}

Istilah "spiritual" berasal dari bahasa inggris dengan kata dasar "spirit" yang memiliki makna antara lain jiwa, roh, semangat, hantu, moral dan tujuan atau makna yang hakiki. Sedangkan dalam bahasa arab istilah spiritual terkait dengan yang ruhani dan ma'nawi dari segala sesuatu. Makna inti dari kata spirit berikut kata jadiannya seperti spiritual dan spiritualitas adalah bermuara kepada kehakikian, keabadian dan ruh. Manusia terdiri dari unsur material dan spiritual atau unsur jasmani dan ruhani. Perilaku manusia merupakan produk tarik menarik antara energi spiritual dan material atau ruhaniah dan jasmaniah. Kepemimpinan spiritual merupakan kepemimpinan yang membawa dimensi keduniawian kepada dimensi spiritual. Tuhan merupakan pemimpin sejati yang mengilhami, mencerahkan, membersihkan hati nurani dan memenangkan jiwa hambaNya dengan cara yang sangat bijaksana melalui pendekatan etis dan keteladanan (Mukaromah, 2018). Konsep kepemimpinan spiritual dikembangkan oleh Fry et al., (2011) yang menjelaskan bahwa kepemimpinan spiritual terdiri dari nilai- nilai, sikap dan perilaku yang diperlukan untuk memotivasi diri sendiri secara intrinsik 
dan memenuhi kebutuhan mendasar bagi kesejahteraan spiritual melalui keterpanggilan (calling) dan keanggotaan (membership) yang secara positif mempengaruhi kesejahteraan karyawan, keberlanjutan dan tanggung jawab sosial perusahaan serta kinerja keuangan. Kepemimpinan spiritual memiliki lima aspek yaitu visi, harapan atau kepercayaan, cinta altruistik, keterpanggilan atau makna dan keanggotaan. Kelima aspek tersebut berproses dalam kepemimpinan spiritual guna memuaskan kebutuhan spiritual sehingga secara positif akan mempengaruhi individu dan organisasi yang selanjutnya dikenal dengan "The Triple Bottom Line" (Fry dan Cohen, 2009).

\section{Spiritualitas di tempat kerja}

Spirit juga sering dimaknai sebagai entitas, makhluk atau sesuatu bentuk energi yang hidup dan nyata, meskipun tidak kelihatan di mata biasa dan tidak punya badan fisik seperti manusia, namun spirit itu ada dan hidup (Hasan, 2010). Keterhubungan dapat dengan diri sendiri, orang lain, alam semesta, Tuhan, atau kekuatan supernatural yang lain. Lebih lanjut bahwa definisi ini melibatkan perasaan didalam diri (inner feeling), terhubung dengan kerja dan koleganya (Gibson et al., 2009). Terdapat berbagai definisi spiritualitas di tempat kerja, seperti pengalaman dan kebermaknaan kerja, komunitas, dan transedence, yang penyebutannya mungkin berbeda dalam berbagai kajian (Pawar, 2013). Spiritualitas di tempat kerja adalah pengakuan bahwa karyawan memiliki kehidupan batin yang memelihara dan dipelihara oleh pekerjaan yang berarti yang mengambil tempatkan dalam konteks masyarakat (Ashmos dan Duchon, 2000). Kinjerski dan Skrypnek (2004) spiritualitas tempat kerja adalah pengalaman yang berbeda dicirikan oleh fitur kognitif, dimensi interpersonal, kehadiran spiritual, dan komponen mistis. Konsep spiritualitas ditempat kerja (workplace spirituality) mencerminkan ekspresi dan pengalaman spiritualitas pada tempat kerja yang difasilitasi oleh berbagai aspek-aspek organisasi, seperti budaya, suasana organisasi (organizational climate), budaya organisasi, kepemimpinan, dan praktik organisasi. Spiritualitas tempat kerja yaitu upaya untuk mencari dan menemukan makna tertinggi kehidupan untuk kehidupan kerja, untuk berkomunikasi antara individu dan rekan-rekan mereka serta orang-orang lain yang entah bagaimana berkontribusi terhadap pekerjaan, juga harmoni atau kesatuan antara individu percaya dengan nilai organisasi mereka.

\section{Efek positif kepemimpinan spiritual pada komitmen organisasi}

Nilai-nilai spiritual dalam kepemimpinan mampu memotivasi dan menginspirasi para karyawan dalam membangun visi dan budaya organisasi serta menciptakan komitmen karyawan terhadap organisasi, yang pada akhirnya juga berdampak pada peningkatan kepuasan kerja dan kinerja karyawan (Rahmawaty, 2016). Studi Fry et al. (2011) mengenai 
model kausal spiritual leadership theory menunjukkan bahwa terdapat hubungan positif spiritual leadership, spiritual survival dengan organizational outcomes, yang terdiri dari komitmen dan produktivitas. Konsep ini sejalan dengan hasil riset E.Sanders, et.al.,(2004), Fry and JR (2008), Fry et al. (2011), Jufrizen et al. (2018) yang juga menemukan bahwa kepemimpinan spiritual memiliki pengaruh signifikan positif terhadap komitmen organisasi. Berdasarkan konsep dan kajian empiris sebelumnya maka hipotesis pertama yang diusulkan sebagai berikut $\left(\mathrm{H}_{1}\right)$; kepemimpinan spiritualitas berpengaruh signifikan positif terhadap komitmen organisasi.

\section{Efek positif kepemimpinan spiritual pada spiritualitas di tempat kerja}

Spritualitas di tempat kerja berarti memandang tempat kerja sebagai tempat yang dihuni oleh orang-orang yang memiliki pikiran (intelek) dan roh, dan percaya bahwa perkembangan roh sama pentingnya dengan mengembangkan pikiran (Ashmos dan Duchon, 2000). Spiritualitas tempat kerja melibatkan upaya untuk mengembangkan hubungan yang kuat dengan rekan kerja yang terkait dengan pekerjaan, dan untuk menumbuhkan keselarasan antara keyakinan inti seseorang dan nilai-nilai organisasi (Milliman et.al., 2003). Spiritualitas di tempat kerja adalah salah satu jenis iklim psikologis di mana para pekerja melihat dirinya memiliki kehidupan internal yang diperlakukan secara bermakna dan ditempatkan dalam konteks komunitas (Duchon dan Plowman, 2005). Hasil penelitian yang dilakukan oleh E.Sanders et.al., (2004), Helmy (2016) menemukan bahwa kepemimpinan spiritual berpengaruh signifikan positif terhadap spiritualitas di tempat kerja. Berdasarkan konsep dan kajian empiris sebelumnya maka hipotesis kedua yang diusulkan sebagai berikut $\left(\mathrm{H}_{2}\right)$ : kepemimpinan spiritualitas berpengaruh signifikan positif terhadap spiritualitas di tempat kerja.

\section{Efek positif spiritualitas di tempat kerja pada komitmen organisasi}

Motivasi internal karyawan dapat dibangun melalui pengembangan spiritual ditempat kerja. Spiritual disini bukan semata-mata religiusitas melainkan semangat dan kepercayaan diri akan makna pekerjaan (Stiadi et al., 2017). Tingkat internalisasi kebutuhan spiritual mempengaruhi perilaku dan harapan seseorang untuk bertindak dan taat serta berkomitmen pada organisasi. Spiritualitas di tempat kerja yang baik didukung oleh sikap kerja dalam bentuk spiritualitas individu yang baik pula sehingga akan mencapai kondisi organisasi yang positif. Hasil penelitian juga menemukan bahwa karyawan pada organisasi dengan tingkat spiritualitas di tempat kerja positif menunjukkan perilaku mendukung organisasi dan menunjukkan komitmen pada tingkatan yang lebih besar daripada karyawan pada organisasi yang tidak memiliki nilai spiritualitas di tempat kerja (Milliman et al. 2003). Sejalan dengan hasil riset (E.Sanders et.al, 2004), Pawar (2009), (Marschke, et.al, 2011), (Jufrizen et al., 2018) juga menemukan bahwa 
spiritualitas di tempat kerja memiliki pengaruh signifikan positif terhadap komitmen organisasi Berdasarkan konsep dan kajian empiris sebelumnya maka hipotesis ketiga yang diusulkan sebagai berikut $\left(\mathrm{H}_{3}\right)$ : Spiritualitas di tempat kerja berpengaruh signifikan positif terhadap komitmen organisasi.

\section{Spiritualitas di tempat kerja mampu memediasi hubungan kepemimpinan spiritual}

\section{dengan komitmen organisasi}

Dalam penerapan kepemimpinan spiritual membutuhkan pengembangan spiritualitas di tempat kerja sehingga karyawan akan merasa nyaman berada pada organisasi tersebut dan meningkatkan komitmen terhadap organisasi (Rahayu, 2016). Karyawan merasa menghayati dirinya sebagai makhluk spiritual. Spiritualitas di tempat kerja juga berkaitan dengan keinginan karyawan untuk memperoleh arti yang terdalam dari pekerjaan yang mereka lakukan, keinginan untuk mewujudkan semangat di tempat kerja, merupakan proses mencari sesuatu yang jauh melampaui dari sekedar pendapatan dan kinerja (Ashmos dan Duchon, 2000), (Kinjerski dan Skrypnek, 2004). Berdasarkan konsep diatas maka hipotesis yang diusulkan adalah (H4): spiritualitas di tempat kerja mampu memediasi hubungan kepemimpinan spiritual dengan komitmen organisasi.

\section{Metode Penelitian}

Populasi dalam penelitian ini adalah seluruh karyawan Perusahaan Daerah Air Minum Kabupaten Badung, Perusahaan Air Minum Kota Denpasar dan Perusahaan Daerah Air Minum Kabupaten Tabanan. Jumlah karyawan masing-masing perusahaan daerah tahun 2019 dapat dilihat pada table berikut:

Tabel: 1 Jumlah Karyawan Masing-masing Perusahaan Daerah Air Minum

\begin{tabular}{lc}
\hline Nama Perusahaan & Jumlah Karyawan (orang) \\
\hline PDAM Tirta Mangutama Kab Badung & 336 \\
PDAM Kapupaten Tabanan & 247 \\
PAM Kota Denpasar & 319 \\
Total & 902 \\
\hline
\end{tabular}

Sumber : PDAM/PAM masing-masing Kabupaten/Kota tahun 2019

Jumlah sampel yang diambil dalam studi ini disesuaikan dengan proporsi jumlah karyawan tiap perusahaan serta menggunakan kriteria yang telah ditetapkan sebelumnya (minimal sudah bekerja selama 5 tahun, merupakan karyawan tetap perusahaan, bersedia untuk mengisi kuisioner dan diwawancarai). Berdasarkan ketentuan yang telah ditetapkan maka diambil sejumlah 200 orang karyawan sebagai sampel penelitian (masing-masing di PDAM Kabupaten Badung sebanyak 74 orang, di PDAM Kabupaten Tabanan sebanyak 71 orang dan 
PAM Kota Denpasar 55 orang).

Penelitian ini menggunakan dua variabel yaitu variabel eksogen dan variabel endogen. Dalam penelitian ini yang menjadi variabel endogen adalah komitmen organisasi $\left(\mathrm{Y}_{2}\right)$, spiritualitas di tempat kerja $\left(\mathrm{Y}_{1}\right)$. Sedangkan yang menjadi variabel eksogen adalah kepemimpinan spiritual (X).

Kepemimpinan spiritual merupakan kepemimpinan yang membawa dimensi keduniawian kepada dimensi spiritual. Kepemimpinan spiritual terdiri dari nilai- nilai, sikap dan perilaku yang diperlukan untuk memotivasi diri sendiri secara intrinsik dan memenuhi kebutuhan mendasar bagi kesejahteraan spiritual. Kepemimpinan spiritual dalam studi ini mengacu pada aspek-aspek yang dikemukakan oleh (Fry dan Cohen, 2009) meliputi visi (spirit1), harapan (spirit2), cinta altruistic (spirit3), keterpanggilan (spirit4), dan keanggotaan (spirit5).

Spiritualitas di tempat kerja adalah persepsi karyawan perusahaan daerah air minum mengenai institusi tempat kerja mereka yang dapat membantu menemukan tujuan hidup, mengembangkan hubungan yang kuat dengan sesama rekan kerja dan orang lain yang berhubungan dengan pekerjaan dan memiliki keselarasan antara keyakinan inti mereka dengan nilai-nilai organisasi tempat mereka bekerja. Variabel spiritualitas di tempat kerja diukur menggunakan dimensi (Ashmos \& Duchon, 2000) yang terdiri dari sense of inner life (rasa batin,wps1), meaningful work (kerja yang bermakna, wps2) dan sense of community (rasa kebersamaan,wps3)

Komitmen organisasi adalah kedekatan karyawan perusahaan daerah air minum masing kabupaten/kota dengan organisasi dimana mereka berada. Sering juga disampaikan bahwa komitmen adalah keterlibatan \& kesetiaan karyawan terhadap organisasi. F Mas'ud, (2002) dalam (Astakoni, 2014) menyatakan bahwa komitmen dibentuk oleh lima indikator yaitu: kepedulian karyawan (komit1), kebanggaan karyawan (komit2), kesenangan karyawan pada organisasi (komit3), keselarasan individu dan organisasi (komit4), kesediaan bekerja ekstra (komit5). Semua indikator atau dimensi dari masing-masing variabel dalam studi ini dinilai dengan skala Likert lima poin mulai dari "1 dengan makna sangat tidak setuju (sts) hingga "5 dengan makna sangat setuju"

Penelitian ini menggunakan teknik pengumpulan data sebagai berikut : 1) Wawancara, dilakukan kepada karyawan yang berkerja di perusahaan daerah air minum Kabupaten Badung ,Kabupaten Tabanan dan Kota Denpasar 2) Kuesioner, yaitu dengan menggunakan beberapa pertanyaan tertutup yang diberikan kepada karyawan perusahaan mengenai komitmen organisasi, spiritualitas di tempat kerja dan kepemimpinan spiritual. 
Analisis studi ini menggunakan pendekatan Partial Least Square (PLS). Menurut Ghozali (2011) PLS merupakan pendekatan alternatif yang bergeser dari pendekatan SEM berbasis kovarian menjadi berbasis varian. Dalam PLS path modeling terdapat dua model yaitu outler model dan inner model. Outler model (measurement model) pada variable laten bersifat refleksif, evaluasi model pengukuran untuk menguji validitas dan reabilitas indikator adalah convergent validity, discriminant validity, composite reliability dan cronbach alpha. Suatu indikator dikatakan valid, jika outer loading > 0,50. Discriminant Validity, suatu variabel dikatakan valid, jika akar $A V E$ ( $\sqrt{ } A V E$ atau Square root Average Variance Extracted) lebih besar dari nilai korelasi antar variabel dalam model penelitian (Ghozali dan Latan, 2012), dan AVE lebih besar dari 0,50. Composite reliability dan Cronbach alpha suatu pengukuran dapat dikatakan reliabel, apabila composite reliability dan cronbach alpha memiliki nilai lebih besar dari 0,70. Dalam evaluasi model struktural dilakukan melalui beberapa pendekatan diantaranya a) $R$-Square $\left(R^{2}\right)$, b) $Q$-Square Predictive Relevance $\left(Q^{2}\right)$, dan c) Goodness Of Fit $(G o F)$. Menurut Chin, dalam Latan dan Ghozali (2012), nilai $R$-Square $\left(R^{2}\right)$ sebesar 0,67 tergolong model kuat, $R$-Square $\left(R^{2}\right)$ sebesar 0,33 model moderat, dan $R$-Square $\left(R^{2}\right)$ sebesar 0,19 tergolong model yang lemah. $Q$ Square Predictive Relevance $\left(Q^{2}\right)$, adalah merupakan pengukur seberapa baik observasi yang dilakukan memberikan hasil terhadap model penelitian. Nilai Q-Square Predictive Relevance $\left(Q^{2}\right)$ berkisar antara 0 (nol) sampai dengan 1 (satu). Kreteria kuat lemahnya model diukur berdasarkan $Q$-Square Predictive Relevance $\left(Q^{2}\right)$ menurut (Ghozali, 2013) adalah sebagai berikut: 0,35 (model kuat), 0,15 (model moderat), dan 0,02 (model lemah). Nilai pengukuran berdasarkan Goodness of Fit (GoF) memiliki rentang nilai 0 (nol) hingga 1 (satu). Kriteria kuat lemahnya model berdasarkan pengukuran Goodness of Fit (GoF) menurut (Ghozali dan Latan, 2012), adalah sebagai berikut: 0,36 (GoF kuat), 0,25 (GoF sedang), dan 0,10 (GoF lemah). Pengujian peran variable mediasi variable organanizational commitmen dalam studi ini dipergunakan Uji Zobel (Zobel Tes), (Ferdinand, 2014:304).

\section{Hasil Penelitian dan Pembahasan}

Penjabaran karakteristik responden dapat dijelaskan dari aspek jenis kelamin, pendidikan terkahir dan lama bekerja pada perusahaan daerah air minum masing-masing. 
Tabel 2. Deskripsi Karakteristik Responden Penelitian Berdasarkan Jenis Kelamin, Masa Kerja \& Pendidikan Terakhir

\begin{tabular}{lcccccc}
\hline Jenis Kelamin & $\begin{array}{c}\text { Lama Kerja } \\
\text { (tahun) }\end{array}$ & SMA/SMK & \multicolumn{2}{c}{ Pendidikan Terakhir (dalam \%) } & \multicolumn{2}{c}{ Total } \\
Diploma & Sarjana & PascaSarjana & (orang) $(\%)$ \\
\hline Laki & $5-10$ & 0 & 12 & 43 & 0 & 55 \\
& $11-15$ & 2 & 6 & 24 & 1 & 33 \\
& $16-20$ & 0 & 2 & 6 & 3 & 11 \\
& $21-25$ & 0 & 0 & 2 & 1 & 3 \\
& $26-30$ & 1 & 0 & 3 & 0 & 4 \\
Perempuan & $>30$ & 2 & 0 & 1 & 1 & 4 \\
& Total Laki & 5 & 20 & 79 & 6 & 110 \\
& (Persentase total) & $(4,50)$ & $(18,20)$ & $(71,80)$ & $(5,50)$ & $(100,00)$ \\
& $5-10$ & 0 & 8 & 24 & 0 & 32 \\
& $11-15$ & 0 & 7 & 30 & 4 & 41 \\
& $16-20$ & 3 & 2 & 7 & 0 & 12 \\
& $21-25$ & 1 & 0 & 2 & 0 & 3 \\
& $26-30$ & 0 & 1 & 0 & 0 & 1 \\
& $>30$ & 0 & 0 & 0 & 1 & 1 \\
& Total Perempuan & 4 & 18 & 63 & 5 & 90 \\
& (Persentase) & $(4,40)$ & $(20,00)$ & $(70,00)$ & $(5,60)$ & $(100,00)$ \\
$5-10$ & 0 & 20 & 67 & 0 & 87 \\
& $11-15$ & 2 & 13 & 54 & 5 & 74 \\
& $16-20$ & 3 & 4 & 13 & 3 & 23 \\
& $21-25$ & 1 & 0 & 4 & 1 & 6 \\
& $26-30$ & 1 & 1 & 3 & 0 & 5 \\
& $>30$ & 2 & 0 & 1 & 2 & 5 \\
& Total & 9 & 38 & 142 & 11 & 200 \\
& (Persentase) & $(4,50)$ & $(19,00)$ & $(71,00)$ & $(5,50)$ & $(100,00)$ \\
\hline
\end{tabular}

Tabel 2 menggambarkan bahwa reponden laki-laki tingkat pendidikannya paling rendah SMA/SMK (4,50\%) dan mayoritas berpendidikan sarjana (S1) sebesar 71,80\%. Untuk responden perempuan kondisinya hampir sama dengan responden laki-laki pendidikannya paling rendah SMA/SMK (4,40\%) dan mayoritas berpendidikan sarjana (S1) sebesar 70,00\%. Secara keseluruhan dilihat dari masa kerja baik gender laki-laki maupun perempuan mayoritas berada pada posisi 5 - 10 tahun dan 11- 15 tahun. Jadi responden yang diangkat dengan pendidikan mayoritas lulusan PT (Sarjana/S1) dan dengan sisa masa kerja yang masih relatif lama, sehingga pihak lembaga/organisasi saat ini memiliki SDM yang masih sangat potensial untuk dikembangkan.

Dalam mengevaluasi indikator-indikator variabel laten dari ketiga variabel yang diangkat dalam studi ini, telah didapat hasil yang memenuhi ketentuan yang ada sebagai berikut: berdasarkan ketentuan convergent validity dari measurement model dengan indikator reflektif dapat dilihat dari nilai AVE minimal 0,600 (AVE > 0,50) dan outler loading minimal 0,636 (diatas >0,50). Hasil perhitungan menunjukkan bahwa ouler loading semua indikator dari variable laten berada diatas 0,50 dan nilai nilai average variance extracted (AVE) diatas 0,5, sehingga syarat keduanya sudah terpenuhi sebagai indikator pengukur kontruk laten. Pengukuran validitas indikator-indikator yang membentuk variabel laten, dapat pula dilakukan melalui 
discriminant validity. Output discriminant validity ditunjukkan lewat HTMT (HeterotraitMonotrait Ratio <0,90) sehingga dinyatakan valid. Output discriminant validity ditunjukkan lewat hasil pengolahan didapat untuk semua kontruk laten dibawah 0,90, sehingga memenuhi syarat discriminant validity. Suatu pengukuran dapat dikatakan reliabel, apabila composite reliability dan cronbach alpha memiliki nilai lebih besar dari 0,70. Composite reliability adalah merupakan suatu pengukuran reliabilitas antar blok indikator dalam model penelitian.Hasil perhitungan menunjukkan bahwa nilai composite reliability seluruh konstruk telah menunjukkan nilai minimal 0,749 (> 0.70) sehingga memenuhi syarat reliable berdasarkan criteria composite reliability dan nilai cronbach alpha yang dihasilkan minimal 0,604 (marginal), akan tetapi ada juga yang memiliki nilai lebih besar 0,70.

Uji Inner Model dipergunakan untuk mengevaluasi model secara keseluruhan.Besarnya koefisien determinasi $\left(\mathrm{R}^{2}\right)$ untuk konstruk komitmen organisasi didapat sebesar 0,708 dan konstruk spiritualitas di tempat kerja didapat sebesar 0,513. Kemudian nilai $Q$ Square Predictive Relevance $\left(\mathrm{Q}^{2}\right)$ didapat sebesar 0,369 untuk kontruk komitmen organisasi dan sebesar 0,104 untuk konstruk spiritualitas di tempat kerja .Sedangkan Goodness of Fit (GoF) untuk kontruk komitmen organisasi sebesar 0,725 (> 0,36 termasuk GoF large), dan untuk konstruk spiritualitas di tempat kerja sebesar 0,456 (> 0,36 termasuk GoF large).Jadi secara keseluruhan model yang dibangun dinyatakan cukup baik. Pengujian hubungan antar konstruk laten seperti yang telah dihipotesiskan dalam penelitian ini dilakukan melalui proses bootstraffing. Gambar 1 dan Tabel 3 memberikan output estimasi untuk pengujian model struktural dari ketiga variabel yang diangkat dalam model.

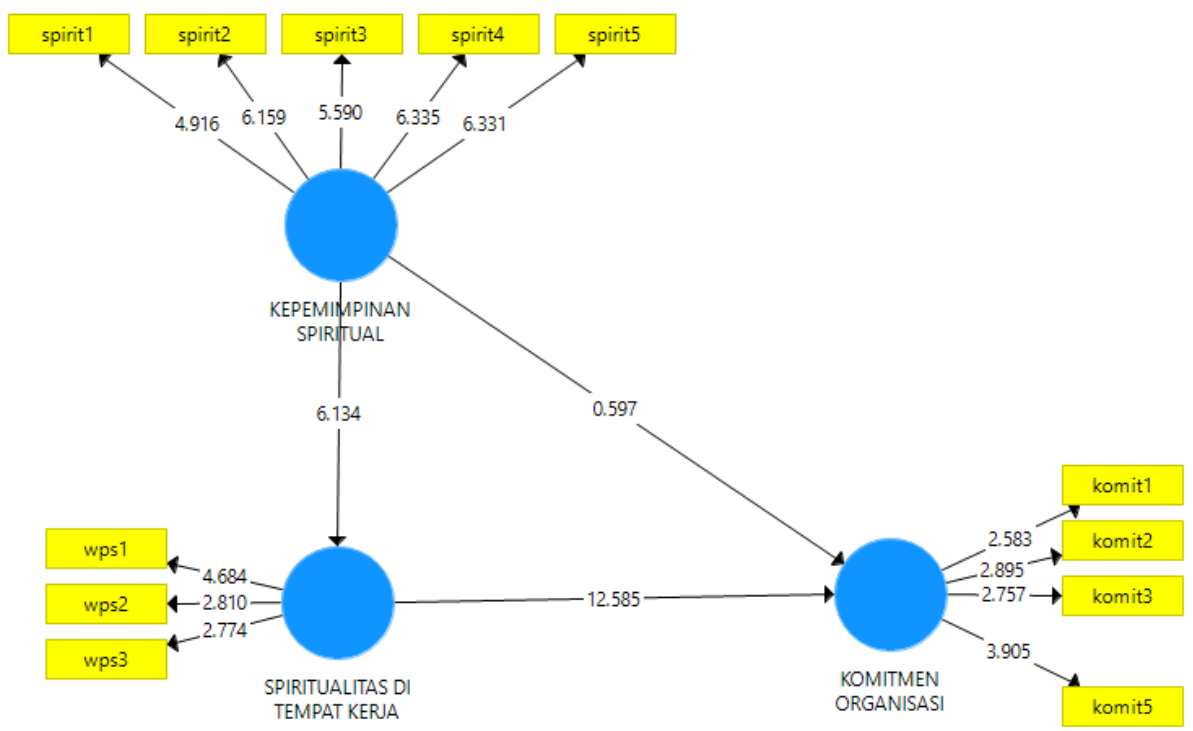

Gambar 1. Hasil uji hipotesis melalui metode bootstraffing 
Tabel 3: Path Analysis dan Hasil Uji Hipotesis

\begin{tabular}{|c|c|c|c|c|c|}
\hline Hubungan Antar Variabel & $\begin{array}{c}\text { Original } \\
\text { Sample } \\
(0) \\
\end{array}$ & $\begin{array}{c}\text { Sample } \\
\text { Mean } \\
(\mathrm{M}) \\
\end{array}$ & $\begin{array}{c}\text { Standard } \\
\text { Dev } \\
\text { (STDEV) } \\
\end{array}$ & $\begin{array}{c}\text { T Statistics } \\
\text { (O/STDEV) }\end{array}$ & p- Value \\
\hline 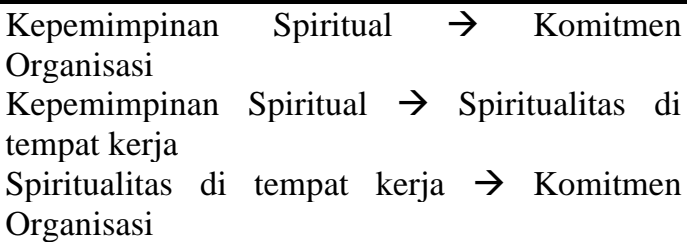 & $\begin{array}{l}0,063 \\
0,716 \\
0,795\end{array}$ & $\begin{array}{l}0,048 \\
0,710 \\
0,808\end{array}$ & $\begin{array}{l}0,105 \\
0,117 \\
0,063\end{array}$ & $\begin{array}{l}0,597 \\
6,134 \\
12,585\end{array}$ & $\begin{array}{l}0,551 \\
0,000 \\
0,000\end{array}$ \\
\hline
\end{tabular}

\section{Efek positif kepemimpinan spiritual pada komitmen organisasi}

Hipotesis 1, kepemimpinan spiritual berpengaruh signifikan positif terhadap komitmen organisasi. Dalam pengujian hipotesis 1, diperoleh bahwa kepemimpinan spiritualitas berpengaruh positif dengan nilai koefisien 0,063 (positif) serta p-value 0,551 (atau t-statistik 0,597 <1,96), berarti hipotesis 1 (H1) belum dapat diterima, sehingga hal ini berarti belum sejalan dengan pernyataan semakin baik kepemimpinan spiritual di perusahaan daerah air minum maka akan semakin tinggi pula komitmen sumberdaya manusianya. Sementara hasil penelitian ini belum mendukung penelitian sebelumnya yang didapat oleh E.Sanders, E.Hopkins, dan Geroy (2004), Fry dan JR (2008), Fry et al. (2011), Jufrizen et al. (2018) yang menemukan bahwa kepemimpinan spiritual memiliki pengaruh signifikan positif terhadap komitmen organisasi.

\section{Efek positif kepemimpinan spiritual pada spritualitas di tempat kerja}

Hipotesis 2, kepemimpinan spiritual berpengaruh signifikan positif terhadap spiritualitas di tempat kerja. Dalam pengujian hipotesis 2, diperoleh bahwa kepemimpinan spiritual berpengaruh positif dengan nilai koefisien 0,716 (positif) serta p-value 0,000 (atau t-statistik 6,134>1,96), berarti hipotesis $2(\mathrm{H} 2)$ dapat diterima, sehingga hal ini berarti semakin baik kepemimpinan spiritual di perusahaan daerah air minum maka akan semakin baik pula spritualitas di tempat kerja pada perusahaan daerah air minum. Hasil penelitian ini sejalan dengan hasil penelitian sebelumnya yang didapat oleh E.Sanders, E.Hopkins, dan Geroy (2004), Helmy (2016) yang menemukan bahwa kepemimpinan spiritual memiliki pengaruh signifikan positif terhadap spritualitas di tempat kerja.

\section{Efek positif spritualitas di tempat kerja pada komitmen organisasi}

Hipotesis 3, spiritualitas di tempat kerja berpengaruh signifikan positif terhadap komitmen organisasi. Dalam pengujian hipotesis 3 , diperoleh bahwa spiritualitas di tempat kerja berpengaruh positif dengan nilai koefisien 0,795 (positif) serta p-value 0,000 (atau t-statistik 12,585>1,96), berarti hipotesis 3 (H3) dapat diterima, sehingga hal ini berarti semakin baik spiritualitas di tempat kerja pada perusahaan daerah air minum maka akan semakin baik pula 
komitmen sumberdaya manusia pada perusahaan daerah air minum. Hasil penelitian ini sejalan dengan hasil penelitian sebelumnya yang didapat oleh (Milliman et al. 2003). Sejalan dengan hasil riset E.Sanders, E.Hopkins, dan Geroy (2004), Pawar (2009), Marschke, Preziosi, dan Harrington (2011), Jufrizen et al. (2018) yang menemukan bahwa spiritualitas di tempat kerja memiliki pengaruh signifikan positif terhadap komitmen organisasi.

\section{Spiritualitas di tempat kerja memediasi hubungan kepemimpinan spiritual dengan} komitmen organisasi

Hipotesis 4, spiritualitas di tempat kerja mampu berperan sebagai pemediasi pada berpengaruh kepemimpinan spiritual terhadap komitmen organisasi. Dalam pengujian hipotesis 4 , melalui uji Sobel didapat koefisien (Z sobel) sebesar 60,666 berarti hipotesis 4 (H4) dapat diterima, sehingga hal ini berarti pengaruh kepemimpinan spiritual terhadap komitmen organisasi teruji secara signifikan jika melalui jalur mediasi spiritualitas di tempat kerja maka akan semakin baik pula komitmen sumberdaya manusia pada perusahaan daerah air minum. Hasil penelitian ini sejalan dengan hasil penelitian sebelumnya yang didapat oleh (Ashmos dan Duchon, 2000), (Kinjerski dan Skrypnek, 2004) yang menemukan bahwa spiritualitas di tempat kerja mampu berperan sebagai pemediasi pada berpengaruh kepemimpinan spiritual terhadap komitmen organisasi. Hal ini sejalan dengan pernyataan Rahayu (2016), yang mengatakan penerapan kepemimpinan spiritual membutuhkan pengembangan spiritualitas di tempat kerja sehingga karyawan akan merasa nyaman berada pada organisasi tersebut dan meningkatkan komitmen terhadap organisasi. Spiritualitas di tempat kerja adalah kesadaran bahwa orang memiliki kehidupan batin yang tumbuh dan ditumbuhkan oleh pekerjaan yang bermakna dan berlangsung dalam konteks komunitas.

\section{Simpulan}

Dilihat dari sisi koefisien determinasi $\left(\mathrm{R}^{2}\right)$, Q-Square Predictive Relevance $\left(\mathrm{Q}^{2}\right)$ dan Goodness of Fit (GoF) maka model secara keseluruhan dinyatakan cukup baik. Hipotesis pertama, yang menyatakan kepemimpinan spiritual berpengaruh signifikan positif terhadap komitmen organisasi belum dapat diterima. Hipotesis kedua, yang menyatakan kepemimpinan spiritual berpengaruh signifikan positif terhadap spiritualitas di tempat kerja, dapat diterima. Hipotesis ketiga, yang menyatakan spiritualitas di tempat kerja berpengaruh signifikan positif terhadap komitmen organisasi, dapat diterima. Berdasarkan pengujian melalui uji Sobel, dapat dijelaskan bahwa spiritualitas di tempat kerja mampu berperan sebagai pemediasi dalam kaitan kepemimpinan spiritual terhadap komitmen organisasi. 
Berdasarkan hasil penelitian dan pengamatan yang telah dilakukan, peneliti dapat memberikan saran kepada manajemen perusahaan daerah air minum untuk tetap menjaga konsistensi dari kebijakan-kebijakan yang diberikan kepada karyawan agar karyawan tetap merasa puas akan pekerjaannya dan selanjutnya karyawan tersebut akan komitmen terhadap organisasi serta memberikan kontribusi yang positif bagi perusahaan. Perusahaan daerah air minum dapat menerapkan kebijakan untuk meningkatkan komitmen karyawan khususnya dalam hal rasa bangga karyawan menjadi bagian dari perusahaan, dengan mengenalkan model-model pendekatan spiritual individu, kelompok dan organisasi. Oleh karena adanya keterbatasan peneliti, maka penelitian ini hanya terbatas pada kepemimpinan spiritual dan spiritualitas di tempat kerja sebagai variabel yang mempengaruhi komitmen organisasional, sehingga untuk penelitian selanjutnya dapat memasukkan faktor-faktor lain yang diduga dapat meningkatkan komitmen baik pada level individu, kelompok maupun tataran organisasi.

\section{DAFTAR PUSTAKA}

Allen, Natalie J., dan John P. Meyer. 1990. The Measurement and Antecedents of Affective, Continuance and Normative Commitment to the Organization. Journal of Occupational Psychology, 63 (1): 1-18.

Armstrong, Michael. 2006. A Handbook Of Human Resources Management Practice. Edisi Kesembilan. London: Cambridge University Press.

Ashmos, Donde P., and Dennis Duchon. 2000. Spirituality at Work: A Conceptualization and Measure. Journal of Management Inquiry 9 (2): 134-144.

Astakoni, Purba I Made. 2014. Analisis Model Keterkaitan Gaya Kepemimpinan, Iklim Organisasi, Karakteristik Individu, Kepuasan Kerja, Komitmen Organisasi Dan Kinerja Karyawan Pada PDAM Tirta Mangutama Kabupaten Badung. Forum Manajemen 12 (2): 92-102.

Duchon, Dennis, and Donde Ashmos Plowman. 2005. Nurturing the Spirit at Work: Impact on Work Unit Performance. Leadership Quarterly 16 (5): 807-833.

E.Sanders, Joseph, Willie E.Hopkins, and Gary D. Geroy. 2004. Spirituality-LeadershipCommitment Relationships in the Workplace: An Exploratory Assessment. Academy of Management Proceedings 2004 (1): A1-6.

Ferdinand, Augusty. 2014. Structural Equation Modeling Dalam Penelitian Manajemen Aplikasi Model-Model Rumit Dalam Penelitian Untuk Skripsi, Tesis Dan Desertasi Doktor. 5thed. Semarang: BP Undip Press.

Fry, Louis W., and Melanie P. Cohen. 2009. Spiritual Leadership as a Paradigm for Organizational Transformation and Recovery from Extended Work Hours Cultures. Journal of Business Ethics 84 (SUPPL. 2): 265-278.

Fry, Louis W., Sean T. Hannah, Michael Noel, and Fred O. Walumbwa. 2011. Impact of Spiritual Leadership on Unit Performance. Leadership Quarterly 22 (2): 259-270.

Fry, Louis W., John R. Latham, Sharon K. Clinebell, and Keiko Krahnke. 2017. Spiritual Leadership as a Model for Performance Excellence: A Study of Baldrige Award Recipients. Journal of Management, Spirituality and Religion 14 (1): 22-47.

Fry, Louis W, and John W Slocum JR. 2008. Maximizing the Triple Bottom Line through 
Spiritual Leadership. Organizational Dynamics 37 (1): 86-96.

Ghozali, Imam. 2011. Aplikasi Analisis Multivariate Dengan Program SPSS 19. Edited by

Prayogo P.Harto. V. Semarang: Badan Penerbit Universitas Diponogoro.

Ghozali. 2013. Aplikasi Analisis Multivariate Dengan Program IBM SPSS 19. Semarang: Badan Penerbit Universitas Diponegoro.

Ghozali, Imam, and Hengky Latan. 2012. Partial Least Square, Konsep-Teknik Dan Aplikasi Smart PLS 2.0 M3. Semarang: Badan Penerbit Universitas Diponegoro.

Gibson, J.L, J. M Ivancevich, J.H Donnely, and Konopaske. 2009. Organization Behavior, Structure, Process. 13thed. New York: Mc Graw-Hill.

Hakim, Abdul, and Azlimin. 2015. Model Peningkatan Komitmen Sumber Daya Manusia Berbasis Spiritual Leadership Dan Spiritual Survival Serta Workplace Spirituality Dengan Moderating Individual Spirituality. Unissula 2 (1): 344-356.

Hasan. 2010. Spiritualitas Dalam Perilaku Organisasi. Dinamika Ekonomi Dan Bisnis 7 (1): 112.

Helmy, Irfan. 2016. Pengaruh Spiritual Leadership Dan Emotional Intelligence Terhadap Organizational Citizenship Behaviour Dengan Workplace Spirituality Sebagai Variabel Intervening. Jurnal Bisnis Dan Manajemen (JBIMA) 1 (1): 72-80.

Jufrizen, Maya Sari, Muhammad Irfan Nasution, Akrim, and Muhammad Fahmi. 2018. Spiritual Leadership And Workplace Spirituality: The Role Of Organizational Commitment. ICEMAB 8 (9): 1-7.

Ke, Jianglin, Fengju Zhang, Xiaocen Yan, and Ya Fu. 2017. The Effect of University Teachers, Workplace Spirituality on Employee Engagement: Professional Commitment as Mediator. Creative Education 8 (13): 2147-54.

Kinjerski, Val M, and Berna J Skrypnek. 2004. "Defining Sprit at Work: Finding Common Ground. Journal of Organizational Change Management 17 (1): 26-42.

Kolodinsky, Robert W., Robert A. Giacalone, and Carole L. Jurkiewicz. 2008. Workplace Values and Outcomes: Exploring Personal, Organizational, and Interactive Workplace Spirituality. Journal of Business Ethics 81: 465-80.

Latan, Hengky, and Imam Ghozali. 2012. Partial Least Squares Konsep Teknik Dan Aplikasi SmartPLS 2.0 Untuk Penelitian Empiris. Edited by Harto Prayogo P. Semarang: Badan Penerbit Univ Diponogoro.

Luthans, Fred. 2009a. Organization Behavior. New Jersey: Pearson Education Inc.

Luthans. 2009 b. Perilaku Organisasi. Edisi Sepuluh. Yogyakarta: Andi.

Mansor, Norudin, Ahmad Haziq Ismail, Mohd Afifie Mohd. Alwi, and Nurhani Anwar. 2013. Relationship between Spiritual Leadership and Organizational Commitment in Malaysians, Oil and Gas Industry. Asian Social Science 9 (7): 179-191.

Marschke, Eleanor, Robert Preziosi, and William J. Harrington. 2011. How Sales Personnel View the Relationship between Job Satisfaction and Spirituality in the Workplace. Journal of Organizational Culture, Communications and Conflict 15 (2): 71-110.

Meyer, John P, and Natalie J. Allen. 1991. A Three Component Conceptualization Organizational Commitment. Human Resource Management Review 1 (1): 1-89.

Milliman, John, Andrew J, Czaplewski, and Jeffery Ferguson. 2003. Workplace Spirituality and Employee Work Attitudes: An Exploratory Empirical Assessment. Journal of Organizational Change Management 16 (4): 426-247.

Mowday, R. T., Steers, R. M., \& Porters, L. W. 1982. Employee-Organization Linka Ges : The Psychology of Commitment, Absenteeism and Turnover. New York: Academic Press.

Mukaromah, Siti Maulidatul. 2018. Kepemimpinan Spiritual (Spiritual Leadership) Guru Sekolah Dasar Dalam Pembentukan Karakter Peserta Didik. Elementary: Jurnal Ilmiah Pendidikan Dasar 4 (1): 63. 
Pawar, Badrinarayan Shankar. 2009. Individual Spirituality, Workplace Spirituality and Work Attitudes: An Empirical Test of Direct and Interaction Effects. Leadership and Organization Development Journal 30 (8): 759-777.

Pawar. 2013. Leadership Spiritual Behaviors Toward Subordinates: An Empirical Examination of the Effects of a Leader's Individual Spirituality and Organizational Spirituality. Journal of Business Ethics 122: 439-452.

Rahayu, Siti. 2016. Kontribusi Kepemimpinan Spiritual Terhadap Komitmen Afektif Melalui Spiritualitas Di Tempat Kerja Pada Karyawan Bank Syariah Di Kota Yogyakarta. Psikologika: Jurnal Pemikiran Dan Penelitian Psikologi 21 (1): 1-11.

Rahmawaty, Anita. 2016. "Model Kepemimpinan Spiritual Dalam Meningkatkan Kepuasan Kerja Dan Kinerja Karyawan Di BMT Se-Kabupaten Pati. IQTISHADIA Jurnal Kajian Ekonomi Dan Bisnis Islam 9 (2): 276-303.

Sopiah. 2008a. Prilaku Organisasional. 1sted. Yogyakarta: PT Andi.

Sopiah. 2008b. Prilaku Organisasional. Edited by Sigit Suyantoro. 1sted. Yogyakarta: PT Andi.

Stiadi, Doni, Meiske Claudia, Ahmad Rifani, Ikhwan Faisal, and Ahmad Supriyanto. 2017. Model Hubungan Workplace Spirituality Terhadap Organizational Commitment Dan Organizational Citizenship Behavior Pada Lembaga Pendidikan. In Prosiding Seminar Nasional AIMI, 27-28.

Sunarso1, Riska Fii Ahsani, and Dorothea Ririn Indriastuti. 2019. Pengaruh Spiritual Di Tempat Kerja Pada Perilaku Kewargaan Organisasional Pekerja Sektor Formal Kota Surakarta. Research Fair Unisri 3 (1): 196-203.

Utami, Ni Made Satya. 2016. Pengaruh Kepemimpinan, Kompetensi Karyawan,Komitmen Organisasi Terhadap Kinerja Karyawan Asuransi Jiwa Bersama Bumi Putra 1912 Kantor Cabang Ubung Denpasar. In Prosiding Seminar Nasional Hasil Penelitian, 15-35. Denpasar: Sekolah Tinggi Ilmu Manajemen Handayani Denpasar.

Utami, Ni Made Satya, and I Made Purba Astakoni. 2020. Peran Gender Sebagai Group Pada Kepemimpinan Path Goal Dan Motivasi Sebagai Determinan Kinerja Guru. Widya Manajemen 2 (1): 36-46.

Yogatama, Leo Agung Manggala, and Nilam Widyarini. 2015. Kajian Spiritualitas Di Tempat Kerja Pada Konteks Organisasi Bisnis. Jurnal Psikologi 42 (1): 1-14. 